\title{
a \\ () \\ OPEN ACCESS \\ Aortobronchial fistula and Listeria endograft infection after repeated T/EVAR: a rare combination
}

\author{
Olivia Lauk, ${ }^{1}$ Rosamaria Fulchini, ${ }^{2}$ Barbara Katharina Hasse, ${ }^{3}$ Isabelle Schmitt-Opitz ${ }^{1}$
}

'Department of Thoracic Surgery, University Hospital Zurich, Zurich, Switzerland ${ }^{2}$ Division of Infectious Diseases and Hospital Epidemiology, Kantonsspital Sankt Gallen, Sankt Gallen, Switzerland ${ }^{3}$ Division of Infectious Diseases and Hospital Epidemiology, University Hospital Zurich, Zurich, Switzerland

Correspondence to

Dr Olivia Lauk;

olivia.lauk@usz.ch

BKH and IS-O contributed equally.

BKH and IS-O are joint senior authors.

Accepted 27 January 2020

Check for updates

(c) BMJ Publishing Group Limited 2020. Re-use permitted under CC BY-NC. No commercial re-use. See rights and permissions. Published by BMJ.

To cite: Lauk $O$, Fulchini $R$ Hasse BK, et al. BMJ Case Rep 2020;13:e229924. doi:10.1136/bcr-2019229924

\section{SUMMARY}

Here we present a rare combination of aortobronchial fistula and Listeria endograft infection after repeat endovascular aortic repair. Device retention, debridement and negative pressure wound therapy, in combination with suppressive antimicrobial therapy, led to satisfactory control of infection until the patient died due to another complication. The combination of an aortobronchial fistula and Listeria endograft infection has never been described before. This present case should encourage and show clinicians the importance of an interdisciplinary approach in highly difficult clinical courses.

\section{BACKGROUND}

Listeria monocytogenes is a Gram-positive, facultative, anaerobic, rod-shaped bacterium. The bacterium crosses the intestinal barrier by endocytosis of endothelial cells, leading to bacteraemia and potential adhesion to the aortic wall or to stent grafts. $L$. monocytogenes is also associated with rare cases of mycotic aneurysm formation. ${ }^{1-3}$

Since the late 1990s thoracic endovascular aortic repair (TEVAR) and abdominal endovascular aortic repair (EVAR) have been increasingly used for repair of aortic pathology in elderly individuals. Thoracoabdominal endovascular aortic repair (T/EVAR) is associated with a lower mortality rate, ${ }^{45}$ with a 30 -day mortality rate of $0.2 \%-1.7 \%$ for endovascular repair compared with $2.3 \%-4.7 \%$ for open surgery. ${ }^{6-8}$ Aortic endograft infection (AGI) is a feared complication with an incidence of $0.2 \%-5 \% .^{9}$ Prolonged antimicrobial treatment and graft excision are usually prerequisites to cure infection. We present the case of L. monocytogenes endovascular AGI complicated by an aortobronchial fistula which was successfully treated with fistula resection, patch repair, debridement, negative pressure wound therapy (NPWT) and graft preservation.

\section{CASE PRESENTATION}

In July 2015, a 70-year-old patient with haemoptysis and intermittent fever presented to the emergency department of the University Hospital Zurich in Switzerland. His medical history was remarkable for a T/EVAR of a large Crawford III thoracic and abdominal aortic aneurysm (figure 1), ${ }^{10}$ a supraaortic and renovisceral debranching, and a coronary artery bypass graft for three-vessel coronary heart disease (all procedures performed in 2007). Additionally a relining of the endovascular prosthesis had been performed in 2010 .
On presentation in July 2015, the patient's C reactive protein (CRP) and leucocyte count were elevated at $209 \mathrm{mg} / \mathrm{L}$ (reference range $<5 \mathrm{mg} / \mathrm{L}$ ) and $14.9 \times 10^{9} / \mathrm{L}$ (reference range $>9 \times 10^{9} / \mathrm{L}$ ), respectively. His haemoglobin was $97 \mathrm{~g} / \mathrm{L}$ (reference range 134-170 g/L). A thoracoabdominal CT angiography (CTA) showed a contrast-enhancing fluid collection around the endovascular stent with progression of the aortic aneurysm. This CTA did not show a fistulous communication between the aorta and the bronchial system. Two sets of blood cultures were drawn but were both negative. Empirical antimicrobial therapy with vancomycin and meropenem was initiated. After 9 days of antibiotics, the patient was still experiencing fever and intermittent haemoptysis. Retention of the endovascular graft was decided in this elderly patient with a high surgical risk. The operation revealed an aortobronchial fistula, and a decision was made to perform resection of the aortobronchial fistula, volume reduction of the infected aneurysm bag and pericardial patch reconstruction. NPWT was initiated and two dressing changes were necessary until wound closure (figure 2). During the second operation, the destroyed left lower lobe of the lung was partially resected under venovenous extracorporeal life support.

Within the first 14 days after lower lobe resection of the lung, the patient's CRP ranged between 70 and $180 \mathrm{mg} / \mathrm{L}$, with a declining trend. Additionally, postoperative blood cultures were negative. After 14 days of empirical treatment and 7 days after the first surgical revision, deep wound cultures were PCR-positive for L. monocytogenes. Additional microbiological cultures of respiratory secretions and from tissue of the fistulous communication grew Klebsiella pneumoniae and Candida albicans. Accordingly, the antimicrobial therapy was de-escalated to amoxicillin/clavulanic acid and gentamicin for L. monocytogenes, and caspofungin was initiated for fungal infection. The patient was transferred to a hospital closer to his home town. Unfortunately, his rehabilitation was complicated by a superinfection of the previously operated aneurysm bag with Pseudomonas aeruginosa and a Stenotrophomonas maltophilia pneumonia. Antimicrobial treatment was changed to piperacillin/tazobactam, and intermittently the patient was treated with trimethoprim/sulfamethoxazole for his pneumonia.

In quarterly clinical follow-ups by an infectious diseases physician, the patient was asymptomatic and remains under lifelong suppressive antimicrobial and antimycotic therapy (outpatient piperacillin/tazobactam pump therapy and fluconazole 


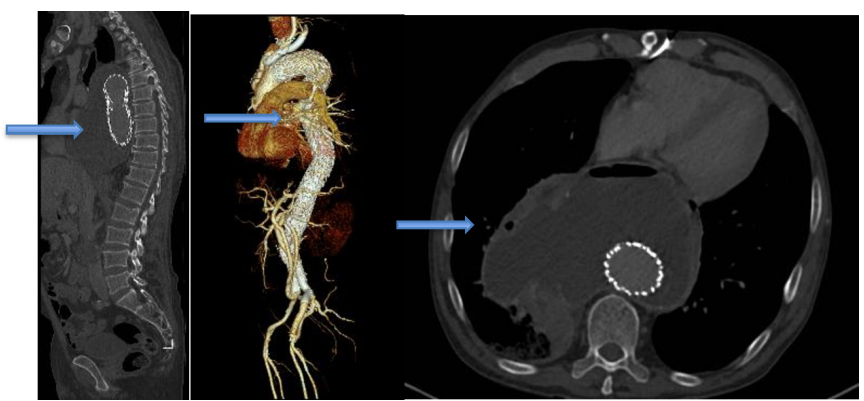

Figure 1 Initial computed tomography (CT) scan in 2015 with infected aneurysm bag (blue arrow).

per os). Repetitive CT scans showed stable conditions of the thoracoabdominal aortic aneurysm with good control of AGI (figure 3).

In November 2017, the patient was hospitalised due to an incarcerated abdominal hernia and subsequent ischaemia of the small bowel. After an emergency operation, the patient developed bilateral pneumonia, paralytic ileus and a new secondary AGI, leading to septic shock and ultimately death in December 2017. Shortly before death, blood cultures and bronchoalveolar lavage were positive for Enterococcus faecium, K. pneumoniae and C. glabrata, without evidence of L. monocytogenes.

\section{OUTCOME AND FOLLOW-UP}

The combination of aortobronchial fistula and Listeria endograft infection has never been described before. Device retention, debridement and NPWT, in combination with suppressive antimicrobial therapy, led to a satisfactory control of infection until the patient died due to another complication.

\section{DISCUSSION}

We report a rare case of $L$. monocytogenes endograft infection presenting as an aortobronchial fistula.

Aortobronchial fistulae are described as potential complications after TEVAR due to very large aneurysms. The incidence of aortobronchial fistulae after TEVAR is estimated at $1.7 \% .^{11}$ Repeat stenting might lead to graft erosion, with the increased pressure from the large aneurysm sac contributing to the occurrence of aortobronchial fistulae. ${ }^{12}$ Similar to the present case, an

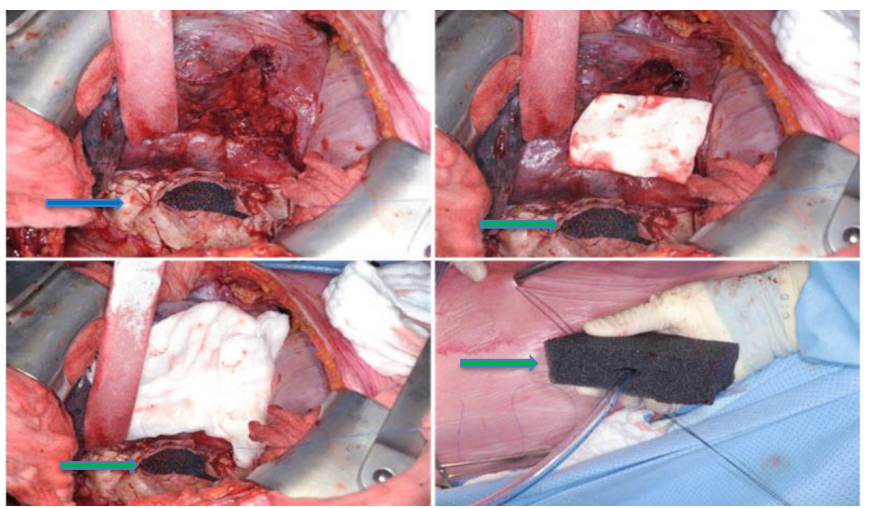

Figure 2 Vacuum sealing/black sponge (green arrow) was placed in the partial resected aneurysm bag and covered up with xenopericardial patch (blue arrow). The images on the top left and right, as well as the bottom left image, the diaphragm and the lung, retracted with the hook, are shown.

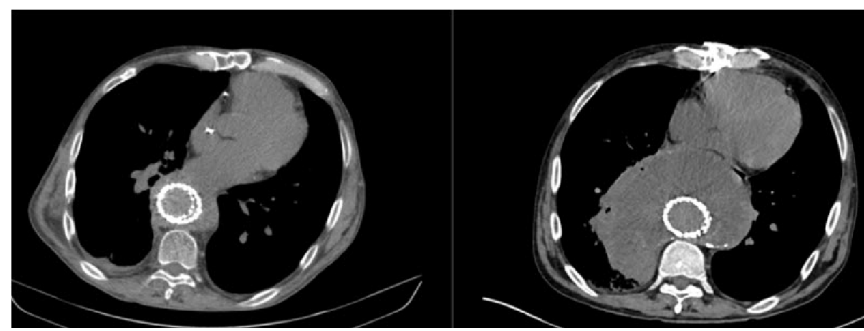

Figure 3 Six-month follow-up without signs of an infected aneurysm bag (left image) compared with the previously infected aneurysm bag (right image).

aortobronchial fistula might also lead to a secondary infection of the thoracic endograft.

The best surgical therapy for AGI is excision of the infected device, debridement of the infected soft tissues, and restoration of the blood flow to the lower extremities and visceral arteries. Surgical options include extra-anatomical bypass or in situ prosthetic graft reconstruction with or without omental wrapping. However, many T/EVAR patients are not suitable candidates for open surgery, and graft excision is associated with high perioperative mortality, ranging from $15 \%$ to $41 \%$. More so in patients undergoing TEVAR with excisions, a more proximal cross clamping of the aorta descendens-associated with potential spinal cord or reperfusion injury-is required, compared with EVAR patients. Additionally, the need for left heart bypass and aortic fistulation complicate the perioperative management. Therefore, in selected patients with high perioperative risk, TEVAR retention might be considered. In our case, a conservative treatment with antimicrobial therapy alone could not control the patient's condition due to the unknown fistula at that time. Therefore, aside from a surgical approach with debridement of the aneurysm sac and a pulmonary parenchymal repair, an NPWT device was used. The application of povidoneiodine-soaked towels in the chest cavity with negative pressure via chest tubes has been previously reported for management of complicated infections. ${ }^{13}$ However, NPWT is not yet well established for intrathoracic use, ${ }^{13}{ }^{14}$ and the most promising effect, when used as an adjunct to surgery, is permanent drainage of the infected area. ${ }^{14}$

L. monocytogenes infection is a foodborne disease that usually affects the elderly or immunosuppressed patients, pregnant women or neonates. Invasive listeriosis usually results in meningitis or bacteraemia. However, rare cases of endograft infections due to L. monocytogenes have also been reported (table 1). ${ }^{1915-18}$

According to the literature, patients with Listeria endograft infection present with fever and/or pain, as was the case in our patient. Additionally, L. monocytogenes is rarely detected in blood cultures and requires selective media for growth from tissue cultures. This indicates that endograft infections with $L$. monocytogenes usually have non-specific symptoms, and therefore clinicians should be vigilant during examination of such patients. ${ }^{3} 1920$ Intravenous penicillin or amoxicillin with or without the synergistic combination of gentamicin is the treatment of choice. The optimal treatment duration is unknown and should be decided based on the extent of infection and the patient's comorbidities. In our patient with retained TEVAR, we decided to go for a lifelong suppressive antimicrobial therapy.

The combination of aortobronchial fistula and Listeria endograft infection has never been described before. Device retention, debridement and NPWT, in combination with suppressive 
Table 1 Reported aortic endograft infections due to Listeria monocytogenes

\begin{tabular}{|c|c|c|c|c|c|c|c|c|c|}
\hline & $\begin{array}{l}\text { Patients } \\
\text { (n) }\end{array}$ & Gender & $\begin{array}{l}\text { Age } \\
\text { (years) }\end{array}$ & Location & $\begin{array}{l}\text { Time after } \\
\text { surgery }\end{array}$ & Surgical treatment & Medical treatment & Follow-up & Outcome \\
\hline Saleem et $a l^{9}$ & 1 & Male & 61 & EVAR & 7 months & Conservative. & $\begin{array}{l}\text { Amoxicillin/clavulanic acid, } \\
\text { cotrimoxazole. }\end{array}$ & $\begin{array}{l}1 \text { year and } 7 \\
\text { months }\end{array}$ & Alive \\
\hline Heikkinen et $a l^{15}$ & 1 & Male & 77 & EVAR & Not stated & $\begin{array}{l}\text { In situ reconstruction with } \\
\text { complete removal of the } \\
\text { infected stent. }\end{array}$ & Not stated. & 10 months & Alive \\
\hline $\begin{array}{l}\text { Cernohorsky et } \\
a l^{16}\end{array}$ & 1 & Not stated & Not stated & EVAR & Not stated & Conservative. & $\begin{array}{l}\text { Amoxicillin/clavulanic acid, } \\
\text { cotrimoxazole. }\end{array}$ & Not stated & Alive \\
\hline $\begin{array}{l}\text { Tanner-Steinmann } \\
\text { and Boggian }{ }^{17}\end{array}$ & 1 & Male & 51 & EVAR & 2 years & Not stated. & Not stated. & Not stated & Not stated \\
\hline $\begin{array}{l}\text { Silvestri and } \\
\text { Isernia }^{18}\end{array}$ & 1 & Female & 72 & TEVAR & 7 years & Conservative. & Cotrimoxazole/gentamicin. & 10 days & Died \\
\hline Heysell $2016^{21}$ & 1 & Female & 68 & TEVAR & 2 years & Conservative. & $\begin{array}{l}\text { Ampicillin/gentamicin } \\
\text { intravenously, } \\
\text { doxycycline per os. }\end{array}$ & 3 years & Alive \\
\hline Yamamoto et al ${ }^{1}$ & 1 & Male & 82 & EVAR & 14 months & $\begin{array}{l}\text { In situ reconstruction with } \\
\text { partial removal of the infected } \\
\text { stent. }\end{array}$ & $\begin{array}{l}\text { Vancomycin, meropenem, } \\
\text { amoxicillin per os. }\end{array}$ & 30 months & Alive \\
\hline Present case & 1 & Male & 70 & TEVAR & 10 years & $\begin{array}{l}\text { Fistula resection, patch repair, } \\
\text { debridement, negative pressure } \\
\text { wound therapy and graft } \\
\text { preservation. }\end{array}$ & $\begin{array}{l}\text { Amoxicillin/clavulanic acid, } \\
\text { gentamicin at the start of } \\
\text { treatment. }\end{array}$ & $\begin{array}{l}2 \text { years and } 4 \\
\text { months }\end{array}$ & Died \\
\hline
\end{tabular}

EVAR, endovascular aortic repair; TEVAR, thoracic endovascular aortic repair.

antimicrobial therapy, led to a satisfactory control of infection until the patient died due to another complication.

\section{Learning points}

- This case should encourage and show clinicians the importance of an interdisciplinary approach in highly difficult and abnormal clinical courses.

- Negative pressure wound therapy is a useful therapeutic approach to intrathoracic infections.

- Endograft infections with Listeria monocytogenes are very rare.

- Repeat thoracoabdominal endovascular aortic repair and realigning procedures may lead to complications.

- Endograft infections, especially with arising fistula, should be treated surgically.

Acknowledgements We thank Walter Weder MD, Ilhan Inci MD, Didier Schneiter $\mathrm{MD}$, Mario Lachat MD and the team of vascular surgery for their clinical contribution.

Contributors OL: drafting the article, critical revision of the article, final approval of the version to be published. RF: critical revision of the article. BKH and IS-O: critical revision of the article and final approval of the version.

Funding The authors have not declared a specific grant for this research from any funding agency in the public, commercial or not-for-profit sectors.

Competing interests None declared.

Patient consent for publication Obtained.

Provenance and peer review Not commissioned; externally peer reviewed.

Open access This is an open access article distributed in accordance with the Creative Commons Attribution Non Commercial (CC BY-NC 4.0) license, which permits others to distribute, remix, adapt, build upon this work non-commercially, and license their derivative works on different terms, provided the original work is properly cited and the use is non-commercial. See: http://creativecommons.org/ licenses/by-nc/4.0/.

\section{REFERENCES}

1 Yamamoto T, Oka K, Kanda K, et al. In situ graft replacement for a ruptured abdominal aortic aneurysm infected with Listeria monocytogenes after endovascular aneurysm repair. Ann Vasc Dis 2018;11:346-9.
2 Bal A, Schönleben F, Agaimy A, et al. Listeria monocytogenes as a rare cause of mycotic aortic aneurysm. J Vasc Surg 2010;52:456-9.

3 Masuda S, Takeuchi N, Takada M, et al. Ruptured thoracic aortic aneurysm infected with Listeria monocytogenes: a case report and a review of literature. Open J Cardiovasc Surg 2013;6:1-7

4 De Bruin JL, Baas AF, Buth J, et al. Long-term outcome of open or endovascular repair of abdominal aortic aneurysm. N Engl J Med 2010;362:1881-9.

5 Brown LC, Thompson SG, Greenhalgh RM, et al. Incidence of cardiovascular events and death after open or endovascular repair of abdominal aortic aneurysm in the randomized EVAR trial 1. Br J Surg 2011;98:935-42.

6 Lederle FA, Freischlag JA, Kyriakides TC, et al. Outcomes following endovascular vs open repair of abdominal aortic aneurysm: a randomized trial. JAMA 2009;302:1535-42.

7 Greenhalgh RM, Brown LC, Kwong GPS, et al. Comparison of endovascular aneurysm repair with open repair in patients with abdominal aortic aneurysm (EVAR trial 1), 30-day operative mortality results: randomised controlled trial. Lancet 2004;364:843-8.

8 Prinssen M, Verhoeven ELG, Buth J, et al. A randomized trial comparing conventional and endovascular repair of abdominal aortic aneurysms. N Eng/ J Med 2004;351:1607-18.

9 Saleem BR, Berger P, Zeebregts CJ, et al. Periaortic endograft infection due to Listeria monocytogenes treated with graft preservation. J Vasc Surg 2008;47:635-7.

10 Crawford ES, Coselli JS. Thoracoabdominal aneurysm surgery. Semin Thorac Cardiovasc Surg 1991;3:300-22.

11 Chiesa R, Melissano G, Marone EM, et al. Aorto-oesophageal and aortobronchial fistulae following thoracic endovascular aortic repair: a national survey. Eur J Vasc Endovasc Surg 2010;39:273-9.

12 Czerny $M$, Reser D, Eggebrecht $H$, et al. Aorto-bronchial and aorto-pulmonary fistulation after thoracic endovascular aortic repair: an analysis from the European registry of endovascular aortic repair complications. Eur J Cardiothorac Surg 2015;48:252-7.

13 Perentes JY, Abdelnour-Berchtold E, Blatter J, et al. Vacuum-assisted closure device for the management of infected postpneumonectomy chest cavities. J Thorac Cardiovasc Surg 2015; 149:745-50.

14 Saadi A, Perentes JY, Gonzalez M, et al. Vacuum-assisted closure device: a useful tool in the management of severe intrathoracic infections. Ann Thorac Surg 2011;91:1582-9.

15 Heikkinen L, Valtonen M, Lepäntalo M, et al. Infrarenal endoluminal bifurcated stent graft infected with Listeria monocytogenes. J Vasc Surg 1999;29:554-6.

16 Cernohorsky P, Reijnen MMPJ, Tielliu IFJ, et al. The relevance of aortic endograft prosthetic infection. J Vasc Surg 2011;54:327-33.

17 Tanner-Steinmann B, Boggian K. Vascular endograft infection with Listeria monocytogenes reated with surgical debridement but without graft removal. Case Rep Med 2011:2011:1-4.

18 Silvestri V, Isernia G. Suspected giant cell aortitis: from multiple aortic structural damage to fatal Listeria sepsis, a case report. Ann Vasc Surg 2017;42:307.e1-6. 


\section{Unusual association of diseases/symptoms}

19 Otowa T, Hirano F, Ashihara J, et al. [Case report; mycotic aneurysm caused by Listeria monocytogenes]. Nihon Naika Gakkai Zasshi 2011;100:1048-50.

21 Heysell SK, Hughes MA. Listeria monocytogenes endovascular graft infection. Open Forum Infect Dis 2016;3:ofv203.

20 Murphy K, Al-Jundi W, Nawaz S. Mycotic aneurysms of the abdominal aorta due to Listeria monocytogenes. Int J Surg Case Rep 2013;4:626-8.

Copyright 2020 BMJ Publishing Group. All rights reserved. For permission to reuse any of this content visit https://www.bmj.com/company/products-services/rights-and-licensing/permissions/

BMJ Case Report Fellows may re-use this article for personal use and teaching without any further permission.

Become a Fellow of BMJ Case Reports today and you can:

- Submit as many cases as you like

- Enjoy fast sympathetic peer review and rapid publication of accepted articles

- Access all the published articles

Re-use any of the published material for personal use and teaching without further permission

Customer Service

If you have any further queries about your subscription, please contact our customer services team on +44 (0) 2071111105 or via email at support@bmj.com.

Visit casereports.bmj.com for more articles like this and to become a Fellow 